\title{
ECOLOGICAL DEVELOPMENT IMPACT ON TOURISM IN PAVLODAR REGION
}

\author{
Aliya Zhakanova Isiksal \\ Near East University, Faculty of Business and Administrative Sciences, Turkey \\ Huseyin Isiksal \\ Near East University, Department of International Relations, Turkey \\ Rakhmetullina Shynar Zhakanovna, Savanchiyeva Armanay Sagatbayevna \\ International University of Kyrgyzstan, Kyrgyzstan \\ Alibek Zhakanov \\ Eurasian National University, Kazakhstan
}

date of paper receipt:

07.08.2017.

Review article date of sending to review:

10.08.2017. date of review receipt:

22.08.2017.

doi: 10.2478/eoik-2018-0009

\section{SUMMARY}

This article analyses the current environmental aspects and the mechanisms of environmental regulation in Kazakhstan with specific emphasis of Pavlodar Region for the development of tourism. The study showed that the environmental situation in Pavlodar Region requires the adoption of a number of activities and legal regulation for improvement and development of tourism. The improvement of tourism is very important for the regional budget and for the overall economic development of the area. It is argued that for the effective management and the development of the tourism industry, the existing taxation system that is the Tax Code of the Republic of Kazakhstan requires some amendments, sustainable development measures should put into the practice with the introduction of technological systems that based upon the use solar and wind energy, and "Green Economy" strategy should be implemented into the practical life and monitored effectively.

Keywords: Pavlodar Region, tourism, ecology, pollutants, taxation.

\section{INTRODUCTION}

Pavlodar Region is an industrial and economically developed region of north-eastern part of Kazakhstan. The region's rich deposits of minerals, favorable geographical position, large reserves of water, the presence of a developed industrial and social infrastructure, and the high technological potential makes it very strategic area. In this connection, the region produces $62.5 \%$ of coal,74\% of ferroalloys and $100 \%$ raw aluminum of Kazakhstan (INVEST IN KAZAKHSTAN). The region also is the main producer of electricity and thermal energy of gasoline.

On the other hand, as a result of the aforementioned intense production sitesPavlodar Region is also subject of pollution. There is no doubt that any modern society may endanger it's future by polluting it's environment. Therefore sustainable development and environmental issues are two interrelated topics that should be deal with the utmost attention. The process of industrialization, which started in Kazakhstan in 2010, led to a structural reorganization of the national economy and became one of key drivers of the economic growth. There is no doubt that at the core of the any economic activity there is production and production is connected with the environment. Most of the production processes have negative impactson the environment. However, for the prosperity of future generations, it is necessary to preserve environmental stability. One of the most important 
foundations for ensuring sustainable development is the construction of an effective system of environmental management and environmental protection (KURMANGALIYEV2011).

The use of nature is one of the most complex objects of management. In modern societies, the development that pollutes and destroys the environment will be meaningless (GAPONOV2004). There are two main modern approaches regarding to managing the equilibrium of ecological and economic systems, namely neo-Classical and neo-Keynasian approaches. In neo-Classical approach there is an economic mechanism based on a system of taxes, payments, etc., built into market relations, which maintains the quality of the environment by the invisible hand of the market. Neoclassical approaches suggest the full compensation to be paid for the economic damage to the environment. In other words, it is relied on the simple principle that the one who pollutespays for the damage.

The second main approach is the neo-Keynesian approach. In the neo-Keynesian approach, the tools of state regulation on the environment are used through the implementation of environmental programs, impact assessment of the environmental projects, and the introduction and regulation of economic instruments. This approach includes scientifically based planning of the amount of costs for environmental protection and rational use of resources to maintain the stability of economic development.

The experiencesin the other parts of the world have shown that there are four possibilities of government intervention in the free market in order to preventpollution and reduce the costs of the resources. These could be summarized as follows (GAPONOV 2004).

1. Direct government regulation and punishment for exceeding the established state standards.

2. Charges from manufacturers as payment for emitted pollution and use of resources.

3. Introduction of a market for rights to pollution and use of resources;

4. Subsidizing environmental protection measures.

According to the Environmental Code of the Republic of Kazakhstan, the types of mechanisms for the economic regulation of environmental protection and nature management are categorized under seven subtitles (ECOLOGICAL RULE REPUBLIC OF KAZAKHSTAN 2007, 212):

1. Planning and financing of environmental protection measures.

2. Payment for emissions into the environment.

3. Payment for the use of certain types of natural resources.

4. Economic incentives for environmental protection.

5. Market mechanisms for managing emissions into the environment.

6. Environmental insurance.

7. Economic evaluation of damage to the environment.

In order to improve the environmental management in Kazakhstan, there are requirement for economic regulation of environmental protection, assessment of economic damage, effective use of mechanisms for the economic regulation of environmental protection and nature management. Being similar to the other parts of Kazakhstan, the environmental situation in the region stands as an important indicator in attracting tourist flows. Tourism is one of the largest high-yielding and most dynamic sectors of the world economy. According to the World Tourism and Travel Council (WTTC)tourism sector employs more than 260 million people all around the world which means every tenth employee in the world is working in this sector. Tourism incomes are not limited with inter-sector revenues. It also has a huge impact on key sectors of the economy, such as transport, communications, trade, construction, agriculture, consumer goods production among many others. In other words, it acts as an accelerator of socio-economic development (BALATSKY et KHALDEEV 1973). 
Deriving from these points, article is organized as follows. Initially, the brief literature review is focuses on tourism and pollution. This is followed by the methodology section that is section three. Section four analyzes the ecological situation of Pavlodar Region including the results of the SWOT analysis.Following the SWOT analysis, the sixth section evaluates recommendations for the solution of the environmental problems in Pavlodar Region. The final section that is section six is the conclusion part of the articlewhich the main arguments are summarized and important findings of the research are re-presented.

\section{LITERATURE REVIEW}

Tourism is a global phenomenon in the modern world economy. Its mass character is a source of active influence on culture, economics, politics, and the social sphere. In other words, the development of tourism is not restricted with economic activity but also it is a socio-economic phenomenon that combines the market aspects of economic ties and the social goals of the development of society. The World Tourism and Travel Council (WTTC) postulates tourism as one of the largest and most dynamic industries of the modern world economy. Tourism sector contribution to world GDP is $10.3 \%$ and it creates at least 260 million jobs at all around the world. Furthermore, tourism is a source of investment in key areas such as transport and communications, trade, construction, agroindustrial complex, production of consumer goods and many others, acting as a catalyst for social and economic development (OVCHAROV 2013, 253).

Tourism industry includes passenger transport (air, water, road, rail) with its extensive network of technical and specialized services so called "secondary" tourism industries. These secondary industries include transport engineering and automotive industry, fuel industry, capital and road construction, souvenir industry, food industry, many branches of agriculture (BALABANOV 2003).

Similarly, Kabushkin $(2002,39)$ considers the tourism industry as a combination of industries in various sectors of the economy, cultural institutions, education and science. Tourism provides the creation of a material and technical base for broad economy; training the workforce and the production, marketing and consumption of tourism products based on the use of natural resources, material and spiritual values of society (BIRZHAKOV 2007).

Bogolyubov and Orlovskaya $(2005,300)$ also noted that tourism sector have connection with other sectors including improvement of pricing; expansion of advertising activities; scientific research; attraction of investments; interaction with other companies; relations with government bodies. Therefore, it is evident that the tourism industry is one of the few sectors of the economy that has the strongest multiplier effect and has a direct impact on many other sectors of the economy. Tourism is able to exert an active influence on the economy of the region.

In this connection, the growing importance of tourism has great influence on the economy of a particular region. For instance, the development of tourism plays an important role in raising the level of education, solving social problems, improving the health care system, and introducing new means of disseminating information (YAFAROV2006). Stating in different words, the development of tourism contributes to the international specialization of a region.

All these factors make tourism one of the priorities of a national economy. This is also valid in greater extend for Pavlodar Region in Kazakhstan. Tourism as a sphere of economic activity has of great importance for the country and it could directly contribute to Kazakhstan and Pavlodar Region in many ways including:

1. Tourism has become one of the leading sectors of the Kazakh economy. It is becoming a pioneer in the development of new job areas, accelerating the development of infrastructure and hotel construction, and stimulating the production of different sectors that are catalyst for the accelerated development of the national economy. As mentioned above, the rapid development 
of tourism contributes to the development of other sectors of the economy: trade, transport, consumer services, production of consumer goods, agriculture, construction and others (MOROZOVA etMOROZOV 2010, 136). Therefore, it is not wrong to argue that tourism has a multiplier effect on growth of the national income along with the employmentand development of local infrastructure that directly contribute to the living standards of the local population.

2. Being similar with many other developing countries, tourism is among the most profitable sectors of the Kazakh economy. Tourism income has become an effective source of receiving foreign currency. By this way it brings a high level of efficiency and a rapid return on investment. As a result of this process, tourism could contribute to a mechanism for the redistribution of national income in favor of regions specializing in tourism.

3. Tourism acts as an effective means of protecting nature and cultural heritage, since it is these elements that form the basis of its point of tourist attraction. In this connection, tourism contributes to the preservation of folk crafts and national culture of regions as in the case of Pavlodar Region (MOROZOV et al 2014, 320).

Without a doubt there is a direct connection with tourism and environmental issues as environmental pollution could directly hinder tourism incomes. As noted byLazarević $(2017,137)$ tourism is more dependent on the environment than any other economic sector. Environment and tourism are interconnected because only a clean and unpolluted environment can be a good base for successful tourism and only in well protected areas tourism can be systematically developed to create economic and social benefits (LAZAREVIĆ2017,138).

Balatsky and Khaldeev (1973) argue that environmental pollution is very important because it brings extra coststo the state budgets. According to them extra bargain of these costs should not be underestimated because they include vast variety of additional costs such as air pollution that has negative consequences not only on economic but also in social life. At the same vein Hoffmann (1985)also puts forward that many industries related with polluting industries brings additional costs to the national economies of the developing countries.

Khachaturov (1982)grouped the costs of the pollution to the national economies into the two categories. The first category outlines the direct losses of the national economy from the destruction of natural resources. The second category refers to loss in the incomes of society due to the deterioration of the quality of natural resources because of the environmental pollution.Balatsky (1984) also defined economic damage as actual and possible losses, caused by the pollution of the environment, expressed in value terms or additional costs to compensate for these losses.

Finally, Mamyrov, Tonkopiy and Upushev (2003) state that to evaluate environmental costs alone could be misleading. Instead, it is necessary to take into account both environmental costs and costs for compensation of damage, including lost profit in the form of unearned income. Similarly, Golub and Strukova (1995)define the economic damage from pollution of the natural environment as a monetary assessment of the negative changes in the main natural properties under the influence of pollution. According to Golub and Strukova, deteriorating environmental changes negatively affect the life conditions of people both socially and economically that further enhances the costs of the pollution than calculated.

\section{METHODOLOGY}

The purpose of this study is to develop practical recommendations for improving the ecological situation and tourism in Pavlodar Region. The data was collected from statistical indicators of the Committee on Statistics of the Ministry of National Economy of Kazakhstan, the Department of Natural Resources and Environmental Management of Pavlodar region. Thereforethis research is based upon the original and primary sources in the form of data from official websites of specialized institutions and authorities of Kazakhstan and Pavlodar Region. 
The objectives of the study could be summarized as follow:

1. To conduct an analysis of the environmental situation in Pavlodar Region.

2. To consider the impact of the ecological situation in the region on the development of tourism.

3. To develop proposals in order to address environmental problems and the development of tourism in Pavlodar Region.

For the proper characterization of environmental problems in accordance with scientific research, this study used thecomparative, statistical, and the SWOT analysis. By using the SWOT method, arguably it is possible to establish lines of communication between the strengths and weaknesses that are inherent in a certain system along with external threats and opportunities.

\section{ANALYSIS OF THE ECOLOGICAL SITUATION IN PAVLODAR REGION}

The economy of Kazakhstan is the largest economy in Central Asia and the second post-Soviet economy after Russian Federation. The Republic of Kazakhstan has rich mineral resources, extensive agricultural lands, qualified personnel, and significant industrial potential. Extractive industries continue to drive the economy of Kazakhstan and the country's growth. Having said this it is worth mentioning that the country is also actively developing diversification strategies. For instance, large industrial facilities are built which lead to a deterioration of the ecology of Kazakhstan as a whole. The pollution in Kazakhstan differs significantly depending on the intensity and structure of pollution, the density of concentration of emission sources, and the composition of components, types of production activities, and specialization of regions. According to Tonkopiy (2000) a great variety of natural and economic conditions of the country is caused by its vast territory that requires a regional approach on solving the environmental problems.

In this respect, Pavlodar Region is a large industrial region with the richest mineral and raw materials base in the country.Large deposits of coal, non-ferrous and rare metals, common salt, building materials are concentrated in the region. The regions' strategic and favorable location connectsit with other states and regions of Kazakhstan along the South-Siberian and Central Siberian railroads, automobile, aviation, pipeline and river modes of transport (HOFFMAN 2005). The region also has a great potential for different aspects of tourism. Sights of the region include natural, archaeological, historical, architectural monuments, and religious constructions. There are also numerous natural water resources in the region, including the Bayanaul State National Natural Park, Zhasybay, Toraygyr, Sabyndykol and Birzhankollakes, whose conditions require special attention due to threat of the pollution made particularly in the Summer season.

Health tourism represents one of the most popular directions of tourism in the world where tourists spend 150\% more than other tourists (DRACHEVA, ZABAEV et ISMAYEV 2005, 576). In this respect, Pavlodar Region enjoys rich potential in terms of health tourism. For instance, the natural salty lake Maralda is well known for the mineralized silt mud giving the improving and rejuvenating effect (ZHAKUPOV et ATASOY 2015).Similarly, Kalatuz salty lake is famous for recreation areas. Also, the effectiveness of the therapeutic mud in the health resort of Sanatorium Moyildy is very famous not only in Kazakhstan but also in the neighboring countries.

Tosumup, therichnaturalandresourcepotential of area, existence of the developed production and social infrastructure, high scientific and technical potential, and its location between Central Asia and Siberia draw close attention of industrial is tsandbusinessmen (ARYNOVA2012).

As demonstrated in the Table 1 below, Pavlodar Region is one of the most economically developed regions in Kazakhstan, which has strategic importance for the whole country. 
Table 1 The main economic indicators of Pavlodar Region

\begin{tabular}{|r|r|r|r|r|}
\hline № & Years & \multicolumn{1}{|c|}{$\begin{array}{c}\text { Gross } \\
\text { regional product } \\
\text { GRP (mln. tenge) }\end{array}$} & $\begin{array}{c}\text { Population, } \\
\text { thousands of } \\
\text { people }\end{array}$ & $\begin{array}{c}\text { Volume of industrial } \\
\text { production (mln. Tenge) }\end{array}$ \\
\hline 1 & 2006 & 441811,8 & 744,9 & 351389 \\
\hline 2 & 2007 & 591977,8 & 746,5 & 464111 \\
\hline 3 & 2008 & 862422,1 & 742,3 & 714344 \\
\hline 4 & 2009 & 862840,7 & 744,4 & 550941 \\
\hline 5 & 2010 & 1031878,6 & 746,2 & 843970 \\
\hline 6 & 2011 & 1520492,6 & 746,6 & 964739 \\
\hline 7 & 2012 & 1520575,9 & 748,0 & 1202392 \\
\hline 8 & 2013 & 1758133,5 & 752,8 & 1334756 \\
\hline 9 & 2014 & 1746774,4 & 755,7 & 1110598 \\
\hline 10 & 2015 & 1827764,6 & 758,5 & 1044224 \\
\hline
\end{tabular}

Source:www.stat.gov.kz

The Gross Regional Product (GRP) is a generalizing indicator of the region's economic activity, characterizing the production of goods and services. The volume of the gross regional product of Pavlodar Region for the year 2015 was 1,827,764.6 million tenge.The share of this ratio in the GRP of Kazakhstanin2015 was 4.5\%. Between 2006 to 2015 there is a tendency to increase in the GRP. Also the population of the region increased to 758.5 thousand people in 2015.

The bulk of the GRP in the region is coming from the industrial sector.Domination in the structure of the GRP of industrial production also determines the resource and raw materials orientation of the region. The volume of industrial production in 2015 in comparison with 2006 increased by 692,835 million tenge or with an alternative definition almost three times. The development of industry is triggered by the intensification of investment activity within the framework of the State Program on Forced Industrial and Innovative Development of Kazakhstan for the periods of 2010-2014 and 2015-2019.

On the other hand, as a negative implication of large industrial sectors such as energy, ferrous and non-ferrous metallurgy, mining, oil refining and chemical industry, Pavlodar Region is subject to high technogenic pollution. This is simply because the production process of these industries is accompanied by large emissions of pollutants into the atmosphere.Needless to say that all these have an adverse effect on the health and social activities of the local population.

Table 2 Indicators of pollutant emissions in Pavlodar Region

\begin{tabular}{|c|c|c|l|c|}
\hline No & Years & $\begin{array}{l}\text { Total pollutants } \\
\text { released into the } \\
\text { atmosphere, } \\
\text { thousand tons }\end{array}$ & $\begin{array}{l}\text { Captured and } \\
\text { neutralized } \\
\text { pollutants, } \\
\text { thousand tons }\end{array}$ & $\begin{array}{l}\text { As a percentage of total } \\
\text { discharged pollutants } \\
\text { from stationary sources }\end{array}$ \\
\hline 1 & 2006 & 583 & 11991,4 & 95,4 \\
\hline 2 & 2007 & 575 & 12323,6 & 95,5 \\
\hline 3 & 2008 & 597 & 13167,0 & 95,7 \\
\hline 4 & 2009 & 561 & 12863,3 & 95,8 \\
\hline 5 & 2010 & 573 & 13435,3 & 95,9 \\
\hline 6 & 2011 & 632,2 & 14261,2 & 95,8 \\
\hline 7 & 2012 & 675,9 & 15487,0 & 95,8 \\
\hline 8 & 2013 & 650,4 & 17327,5 & 96,4 \\
\hline 9 & 2014 & 610,2 & 15104,9 & 96,1 \\
\hline 10 & 2015 & 553 & 13724,3 & 96,1 \\
\hline
\end{tabular}

Source: www.stat.gov.kz 
The Table 2 indicates the pollutant emissions in Pavlodar Region between 2006 and 2015. Emissions of pollutants in the atmosphere are understood as the entry of polluting substances into the atmosphere. It includes substances from both stationary and mobile sources of emissions. All pollutants entering the atmospheric air are taken into accountboth after the passage of dust and gas treatment plants that is a result of incomplete collection and purification on organized sources of pollution. These pollutants are also not purificatedfrom the organized and the unorganized pollution sources.

As can be seen from the Table 2, in 2012the greatest emissions of pollutants with $95.8 \%$ are the pollutants discharged from stationary sources.Most of these are caught and rendered harmless. However, the main sources of the atmospheric pollution in Pavlodar Region are the Category I enterprises of environmental hazard which form $85-86 \%$ of the total mass of emissions. This category includes thermal and electric stations operating on high-ash coals and the gross emissions. The share of formation of gross emissions of other large nature users of a similar category varies in the zone of $10 \%$. The remaining $4 \%$ of emissions is formed as a result of economic activity of enterprises of the II, III, IV category of environmental hazard.In this respect it is necessary to note that the annual emissions of pollutants into the air are growingbecause of the users of this category alongwith the growth of production and the number of newly opened production facilities and plots.

Table 3 Emissions of the most common atmospheric pollutants that depart from stationary sources by the Pavlodar Region

\begin{tabular}{|c|c|c|c|c|c|c|}
\hline \multirow[b]{2}{*}{ Years } & \multirow{2}{*}{$\begin{array}{l}\text { Total pollutants } \\
\text { released into } \\
\text { the atmosphere, } \\
\text { thousandtons }\end{array}$} & \multicolumn{2}{|c|}{ including: } & \multicolumn{3}{|c|}{ Gaseou sand liquid substances, including: } \\
\hline & & solids & $\begin{array}{l}\text { Gaseousand liquid } \\
\text { substances }\end{array}$ & $\begin{array}{l}\text { Sulfurousan } \\
\text { hydride }\end{array}$ & $\begin{array}{l}\text { oxides of } \\
\text { nitrogen }\end{array}$ & Carbonmonoxide \\
\hline 2006 & 583 & 251 & 332 & 211 & 68 & 29 \\
\hline 2007 & 575 & 240 & 335 & 215 & 69 & 28 \\
\hline 2008 & 591 & 246 & 351 & 222 & 72 & 30 \\
\hline 2009 & 561 & 220 & 341 & 216 & 61 & 31 \\
\hline 2010 & 573 & 206 & 367 & 231 & 75 & 34 \\
\hline 2011 & 632 & 196 & 436 & 276 & 81 & 53 \\
\hline 2012 & 676 & 180,0 & 496 & 291 & 97 & 75 \\
\hline 2013 & 650 & 153,0 & 497 & 283 & 105 & 85 \\
\hline 2014 & 610 & 136 & 474 & 266 & 103 & 79 \\
\hline 2015 & 553 & 122 & 431 & 244 & 174 & 77 \\
\hline
\end{tabular}

Source: www.stat.gov.kz

As could be seen in the Table 3, half of the total volume of atmospheric emissions of sulfur dioxide falls on non-ferrous metallurgy enterprises. The fuel industry and ferrous metallurgy are the main air pollutants of carbon monoxide emissions. Electricity companies emit nitrogen oxides, solids and sulfur dioxide into the atmosphere. 
Table 4 Expenses on the Environmental Protection

\begin{tabular}{|c|r|r|r|}
\hline Years & $\begin{array}{c}\text { Investments aimed } \\
\text { at protecting the } \\
\text { environment and rational } \\
\text { nature management, } \\
\text { (mln.tenge) }\end{array}$ & $\begin{array}{c}\text { Current costs on } \\
\text { environmental protection } \\
\text { (mln. tenge) }\end{array}$ & $\begin{array}{c}\text { Expenses for capital repairs } \\
\text { of production funds for } \\
\text { environmental protection } \\
\text { (mln. tenge) }\end{array}$ \\
\hline 2006 & 1986,4 & 5967,1 & 495,0 \\
\hline 2007 & 2872,8 & 6857,6 & 722,9 \\
\hline 2008 & 7689,7 & 11254,8 & 3351,1 \\
\hline 2009 & 3271,8 & 17750,1 & 597,8 \\
\hline 2010 & 11379,6 & 12250,8 & 1147,2 \\
\hline 2011 & 10412,0 & 17152,4 & 3879,9 \\
\hline 2012 & 14551,8 & 17926,5 & 4078,3 \\
\hline 2013 & 8454,0 & 15689,7 & 5556 \\
\hline 2014 & 12408,2 & 16265,8 & 24357,04 \\
\hline 2015 & 7661,0 & 16696,01 & \\
\hline
\end{tabular}

Source: www.stat.gov.kz

In 2015, investments aimed at protecting the environment and rational nature management in Pavlodar Region amounted to 7,661.0 million tenge. That also means it increased by 5674.6 million tenge in comparison with 2006, but did not reach to the 2012 level. On the other hand in 2015 the current costs for environmental protection of enterprises and organizations of all forms of ownership in the region amounted to $16,696.01$ million tenge, which is almost three times more than in 2006.

Table 5 Total volume of provided tourist services and its contribution to the economy of Pavlodar Region.

\begin{tabular}{|c|c|c|c|c|c|c|}
\hline No & Years & $\begin{array}{c}\text { Gross regional } \\
\text { product (GRP) } \\
\text { mln. Tenge }\end{array}$ & $\begin{array}{c}\text { Volume } \\
\text { of performed } \\
\text { Works and services in } \\
\text { the field of tourism, } \\
\text { Mln.tenge }\end{array}$ & $\begin{array}{c}\text { Share in } \\
\text { GRP\% }\end{array}$ & $\begin{array}{c}\text { The number } \\
\text { of visitors } \\
\text { served }\end{array}$ & $\begin{array}{l}\text { The number } \\
\text { of employees } \\
\text { employed in } \\
\text { tourism sector }\end{array}$ \\
\hline 1 & 2006 & 441811,8 & 702,9 & 0,16 & 98350 & 730 \\
\hline 2 & 2007 & 591977,8 & 665,8 & 0,11 & 95105 & 900 \\
\hline 3 & 2008 & 862422,1 & 832,7 & 0,09 & 111981 & 895 \\
\hline 4 & 2009 & 862840,7 & 962,8 & 0,11 & 83006 & 1167 \\
\hline 5 & 2010 & 1031878,6 & 1247,4 & 0,12 & 98756 & 829 \\
\hline 6 & 2011 & 1520492,6 & 1637,6 & 0,11 & 119247 & 917 \\
\hline 7 & 2012 & 1520575,9 & 1808,2 & 0,12 & 124273 & 848 \\
\hline 8 & 2013 & 1758133,5 & 1450,7 & 0,08 & 94174 & 843 \\
\hline 9 & 2014 & 1746774,4 & 1612,3 & 0,09 & 105544 & 918 \\
\hline 10 & 2015 & 1827764,6 & 1550,5 & 0,08 & 110456 & 870 \\
\hline
\end{tabular}

Source: Republic of Kazakhstan Official Statistics Institute. Available at:www.stat.gov.kz 
As could be seen from the Table 6, the volume of work performed and services in tourism amounted to 1550.5 million tenge in 2015. This number is much higher than 2006 by 874.6 million tenge. Similarly the share in GRP raised by $0.08 \%$, and there is also an increase in the number of served visitors in 2015 compared to 2006 by 12,106 people. In this connection, the number of employees employed in tourism amounted to 870 people in 2015 according to the official statistics.

In the structure of current costs, it is necessary to protect and use the water resources rationally, to protect the atmospheric air, to protect the land from pollution of production and consumption wastes, and to reclaim land as much as possible.The cost of capital repairs of the main production assets for environmental protection in 2015 amounted to KZT 24,357.04 million. Out of the total amount, the funds were used for capital repairs, for the repair of facilities and installations for the protection of atmospheric air, and for the protection and rational use of water resources.

The main problems associated with waste disposal are a low level of processing and utilization of industrial wastes from the large users of the region. One other problem is the usage of oldtechnologies and inadequate level of utilization of rock piles of the mining industry. Under the current situation in the region, domestic waste management leads to dangerous pollution of the environment. Also,the irrational use of natural resources and related economic damage threat the health of the local population.

There are also problems of solid waste disposals and landfills in the region. The problem of spontaneous landfills remains one of the most criticalenvironmental problems in the region, despite periodic sanitary cleaning.In most cases, landfills do not meet the requirements of sanitary regulations and environmental standards for burial. Recycling of solid domestic waste and using them as secondary raw materials is practically not possible because there is no waste processing factories.

In order to identify the most important environmental problems and propose the solutions that could overcome these problems, a SWOTanalysis of the environment of Pavlodar Region is carried out in Table 5.

Table 6 SWOT analysis of the environment in Pavlodar Region

\begin{tabular}{|c|c|}
\hline $\begin{array}{l}\text { Strengths: } \\
\text { 1. The leading region in Kazakhstan in } \\
\text { terms of mineral and raw materials. } \\
\text { 2. The Bayanaul State National Nature } \\
\text { Park is located in the region. } \\
\text { 3. State programs that contribute to the } \\
\text { development of the region are effectively } \\
\text { implementing in the region. } \\
\text { 4. Many big industrial enterprises comply } \\
\text { with environmental protection measures. } \\
\text { 5. In order to protect the environment, } \\
\text { the costs of the activities in the region are } \\
\text { increased. }\end{array}$ & $\begin{array}{l}\text { Weaknesses: } \\
\text { 1. An unfavorable ecological situation. } \\
\text { 2. Large amounts of emissions rise to the } \\
\text { atmosphere belong to the enterprises of } \\
\text { heat power engineering, metallurgy,and } \\
\text { coal mining industry. } \\
\text { 3. Imperfection of legislation in the field of } \\
\text { environmental payments. } \\
\text { 4. The processing and recycling of } \\
\text { production wastes is not sufficiently } \\
\text { developed. } \\
\text { 5. Thelack of waste processing factories. }\end{array}$ \\
\hline $\begin{array}{r}\text { Opportuniti } \\
\text { 1. Using the other countr } \\
\text { in environmental protec } \\
\text { processing of produc } \\
2 \text { The use of natural o } \\
\text { development of to }\end{array}$ & $\begin{array}{l}\text { Threats: } \\
\text { 1. Negative impact of emissions of } \\
\text { pollutants on the environment and public } \\
\text { health. } \\
2 \text { The impact of the global economic crisis } \\
\text { that reduce the solvency of enterprises on } \\
\text { environmental payments. }\end{array}$ \\
\hline
\end{tabular}

This analysis demonstrates that despite the investments directed to the environmental protection and the work and management of state authorities in the area, the environmental situation in the 
region requires the implementation of certain measures in order to improve it. In this regard, the development of measures should address reducing emissions of harmful substances into the atmosphere.This problem is one of the most urgent contemporary problems not only in Pavlodar Region, but also in whole Kazakhstan.

\section{RECOMMENDATIONS FOR THE SOLUTION OF THE ENVIRONMENTAL PROBLEMS IN PAVLODAR REGION}

In order to solve the environmental problems in Pavlodar Region, first of all sustainable development measures should put into the practice. This requires a resource-saving program-targeted approach for the use of natural resources.In order to achieve this, artificially created means of production should replace the use of natural resources. In this connection, the introduction of technological systems that based upon the use solar and wind energy is essential.

The next stage is the ecologization of the economy. Ecologization of the economy is not anew problem. At the contemporary times, this is realized through the transition to a green economy. In 2013, the government developed and adopted the concept on transferring to "Green Economy." Its basic goal is to provide reliable, adequate and accessible energy resources for substantial social, economic, and ecologically stable growth of the country (BEKNIYAZOVA et al 2016, 602). It puts clear guidelines for building a stable and efficient economy model based on the country's transition to the "green path" of development (GOLUB 1995). For this purpose, nine working groups have been formed by the Presidential Council including (BEKNIYAZOVA et al 2016, 603):

1. Decrease in the air pollution.

2. Training and forming ecological culture of the population.

3. Energy conservation and increase in Energy Efficiency.

4. Eco-systems management.

5. Water resources management.

6. Development of agriculture.

7. Wastes management.

8. Development of electric power including renewable resources of energy

Therefore, for the effective solution of the environmental problems in Pavlodar Region "Green Economy" strategy should be implemented into the practical life and monitored effectively.

Education and advocacy within the waste management system are among the most important issues in the perspective of the resource management system. In addition, for implementation of the strategic goals, specific methods of environmental management should be defined. Economic methods of management of nature consist of prices, tariffs, payments, penalties, bonuses, economic incentive funds, loans, etc.

Article 101 of the Environmental Code of Kazakhstan provides payment for emissions to the environment. The payment is established by the tax legislation of Kazakhstan. According to the Paragraph 4 of Article 1 of the Environmental Code the emissions into the environment that is subject to payment defined as emissions, discharges of pollutants, disposal of industrial waste, consumption in the environment, and the harmful physical effects.

Emission standards are established separately for each ingredient in accordance with the Decree of the Government of Kazakhstan No. 557 of 30.06.2007 "On approval of the list of pollutants and waste types for which emission standards are established". In the Chapter 1 Article 16 of this list the standards aredeclared for other pollutants. These standards are defined as first and second class of hazard compounds for the sanitary and hygienic standards of Kazakhstan. In this list the maximum permissible concentrations and approximatesafe exposure levels in the atmospheric air of populated areas are also established.

On the basis of Paragraph 2 of Article 475 of the Tax Code, the nature users of the region make payments on 16 ingredients. On the other hand,for the substances varying in an amount from 35 to 50, no payment is made to the state budget (KHUILIP 2007). Therefore, it is necessary to amend the Tax Code of Kazakhstan 
with the inclusion of all the substances to taxation.

In modern conditions, these changes would affect the operation of the enterprises that pollute the air. These enterprises should report to the fiscal authorities on the targeted use of funds for the pollution of the environment. Hence, there would be more revenue for the state that could be used for the environment. The required funds may accumulate from the environmental fund of the enterprises that pollute the environment.The funds collected by the government could be used for modernization, technical reequipment, and eco-innovation. In consequence, as a result of changes in the taxation and the development of the funds coming from the enterprises, environmental sustainability in the region could be satisfied that would automatically lead the development of tourism.

\section{CONCLUSION}

One of the most important directions of economic growth in a market economy is the search for adaptation of the opportunities for development and improving production efficiency. This efficiencyshould be based on rational nature management and environmental protection. In order to maintain an environmentally sustainable future, careful monitoring of the natural environment, rationing and prevention of industrial emissions, development, and introduction of waste-free and resource-saving technologies, and the application of environmentally less harmful technologies and industries are needed.

For incomplete mandatory payments for emissions to the environment, it is necessary to amend the Tax Code of Kazakhstan and include substances to the list of pollutants and waste types for taxation. By this way the funds could be raised to be used for modernization and technical re-equipment.

In order to solve problems related to the management of production and consumption waste, it is suggested that environmental legislation in the field of waste management should be improved, low-waste production should be introduced, the used waste components should be recycled and a waste processing factory should be built.

There is little doubt that solving the above problems will improve the ecological situation in Pavlodar Region along with enhancing region's potential for tourism development.Tourism is one of the most promising sectors of the Kazakhstan economy. The experiences of the leading countries all around the world demonstrate that the development of tourism directly contributes to the well-being of the populationthrough income generation, the creation of jobs, and reducing the level of poverty.

Based on the analysis of the current state of the environmental situation in the region, there is a need for investment and research for the 'greening' of the tourism industry.Arguably, this should be part of the country's transition to the "Green Economy" as well.The transition to a "Green Economy"could allow Kazakhstan to achieve its goal of becoming among the top 30 most developed countries in the world. In other words, green economyis one of the most important tools for ensuring sustainable development of the country.

In this connection, one of the key projects of Kazakhstan at the contemporary times is the holding of the international exhibition EXPO-2017 on the theme of "Energy of the Future" in Astana. The initiative of organizing such a large-scale event in the capital of Kazakhstan under the initiative of President Nazarbayev demonstrates the commitment of the country to sustainable development and energy. EXPO-2017 is a new stage in the economic, social and cultural life of Astana in particular and Kazakhstan in general. EXPO exhibitions are the most prestigious and authoritative exhibition venues in the world that are visited by millions of tourists all around the world.

With this project, energy-efficient design and energy storage will start to be used soon.By this way it is aimed to reduce energy consumption by 60 percent. With the replacement of the street system of batteries to the maximum capture of solar energy,there will be significant energy saving especially in the colder months. Not only the heating costs will be reduced but also the comfort of the residents and the ergonomics of the open space will be improved. Furthermore, the holding of EXPO-2017 became an additional stimulus for the economy and the development of the infrastructure both in the capital and within the whole country. 


\section{REFERENCES}

ARYNOVA, Z. A. The priority directions of development of the Pavlodar area till 2015. In North East Asia Academic Forum Pavlodar: Kainar University Press, 2012.

BALABANOV I.T., and A.I.BALABANOV. Tourism Economics Moscow: Finance and Statistics, 2003.

BALATSKY, O. F. Economics and quality of the environment. Leningrad: Hydrometeo Press, 1984.

BALATSKY, O. F., and V. T. KHALDEEV. Choice of the systemic factor in the correlation analysis of the urban citizens. Moscow: IOKG, 1973.

BEKNIYAZOVA,D. S.,A.AKISHEV, I. KALIYEV, G. T. SHAMSHUDINOVA, and M. A. ALTYBASSAROVA. "Innovations as Drivers of Stable Growth of the Kazakh Economy through State Policy in Area of Eco-innovations Implementation". International Journal of Energy Economics and Policy. 6 (3), 2016: 602-610.

BIRZHAKOV, M.B. Introduction to tourism. St. Petersburg: Gerd Publishing House, 2007.

BOGOLYUBOV, V. S., and V.P. ORLOVSKAYA. Tourism Economics. Moscow: Academy, 2005.

DRACHEVA, E.L.,L.V. ZABAEV, and D.K.ISMAYEV. Economy and Tourism Organization. international tourism. Edited by Ryabova, I. A, Zabaeva, J. V.,andDracheva, E. L. 2nd Edition. Moscow: Knopus, 2005.

Ecological Rule Republic of Kazakhstan. No 212, 2007.

FROLOVA,T.A. Economics and management in the field of social and cultural services and tourism: Lecture notes. Taganrog: TTIYUFU, 2010.

GAPONOV, V.V. Nature using. Vladivostok: TIDOT, 2004.

GOLUB, A.A., and E.B. STRUKOVA. Economics of Nature use.Moscow: Aspect Press, 1995.

HOFFMANN, K. G. Economic Problems of Nature Use. Moscow: Science Press, 1985.

Invest in Kazakhstan. Available at: http://invest.gov.kz/pages/investicionnye-vozmozhnosti-regionapavlodarskoy-oblasti

KABUSHKIN.N.I. Tourism Managment. Minsk: New Knowledge, 2002.

KHUILIP, C. International tourism in the modern market conditions. PhD. Dissertation: Southern Federal University. Rostov-on-Don, 2007.

KURMANGALIYEV, A. A. "Ecological problems of the sustainable development of RK."Vestnik6, 2011: 15-19.

LAZAREVIĆ, M. "Influence of Tourism on the Environment". Economics.5 (1), 2017: 137-150.

MAMYROV,N. K., M. S. TONKOPIY, andE.M. UPUSHEV. Economics of nature use. Moscow: Finance \& Statistics, 2003.

MOROZOV, M. A.,N. S.MOROZOVA,G. A. KARPOVA, andL. V.KHOREVA. Tourism Economics. Moscow: Federal Agency for Tourism, 2014.

MOROZOVA N. S.,andM. A. MOROZOV. Entrepreneurship and competition in tourism. Moscow: Ros NOU, 2010.

OVCHAROV, A.O. Tourism Economics. Moscow: Infra-M, 2013.

Republic of Kazakhstan Official Statistics Institute. Available at: www.stat.gov.kz

TONKOPIY, M. C. Economics of Nature Use. Almati: Economics, 2000.

World Tourism and Travel Council (WTTC).Available at: https://www.wttc.org/

YAFAROV,R.K. The impact of tourism on the socio-economic situation of the region. Ph.D. Dissertation. Saratov: University of Saratov, 2006.

ZHAKUPOV, A.,and E. ATASOY. "The potential of development of medical and improving tourism in the Pavlodar Region. Journal of Tourism Theory and Research". 1 (1) 2015: 1-7. 